\title{
Costuming in Seán Keating's self-portraits: theatrical guise or political disguise?
}

\section{Valérie Morisson}

\section{Q OpenEdition \\ 1 Journals}

\section{Electronic version}

URL: http://journals.openedition.org/etudesirlandaises/5520

DOI: 10.4000/etudesirlandaises.5520

ISSN: 2259-8863

\section{Publisher}

Presses universitaires de Caen

\section{Printed version}

Date of publication: 30 May 2018

ISBN: 978-2-7535-7578-3

ISSN: 0183-973X

\section{Electronic reference}

Valérie Morisson, « Costuming in Seán Keating's self-portraits: theatrical guise or political disguise? », Études irlandaises [Online], 43-1 | 2018, Online since 30 May 2018, connection on 13 September 2019. URL : http://journals.openedition.org/etudesirlandaises/5520; DOI : 10.4000/etudesirlandaises.5520

This text was automatically generated on 13 September 2019.

(c) Presses universitaires de Rennes 


\title{
Costuming in Seán Keating's self- portraits: theatrical guise or political disguise?
}

\author{
Valérie Morisson
}

1 In her two volumes on Irish painter Seán Keating (1889-1977), Seán Keating, Art Politics and the Building of the Irish Nation and Seán Keating in Context: Responses to Culture and Politics in Post-War Ireland, Éimear O'Connor shows that while Keating "has been written in Irish history as the bulwark against modernism in Irish art"1, it is worth reevaluating his career and artistic output. Keating is easily defined as a traditional academic painter whose works unreservedly celebrate the Irish nation. The beginning of his training and career as a painter in Dublin coincided with a period of intense political trouble: the Easter Rising (1916), the War of Independence (1919-1921) and the Civil War (1922-1923). The Dublin Metropolitan School of Art "provided an invigorating visual and literal embodiment of politics in general, and nationalism in particular" ${ }^{2}$. Keating's figurative scenes emblematize visual nationalism and have contributed to founding nationhood ${ }^{3}$. He was also earnestly committed to establishing an Irish school of painting.

2 Trained by William Orpen, who always remained a mentor ${ }^{4}$, he devoted much of his time to portraiture. But it is his self-portraits that this paper intends to scrutinize and, more specifically, the role played by dress in these compositions. As a matter of fact, Seán Keating repeatedly staged himself in costume. O'Connor describes the artist as a secretive person unwilling to talk much about his family life and political stance ${ }^{5}$ : "Keating was very private. He did not talk much about his past, and if he did, the information was frequently confused"6. His numerous self-portraits seem to fill in some blanks as if costuming freed him from such secretiveness.

In a self-portrait, Pascal Bonafoux observes, "the costume, the written words, the pose, everything is meaningful, no detail is incidental. Every thing is a sign, bearing the stamp of identity; all that surfaces in the portrait is to be deciphered". Such deciphering, he adds, is a matter of tentative hypothesis as we never stand on firm grounds. Keating's 
self-portrayals may have offered him the opportunity of a daily routine of works, as Éimear O'Connor suggests:

It was for this reason too, and not for the purposes of vanity or conceit, that Keating made so many self-portraits throughout his career. He was following Orpen's directive about the necessity of a daily routine of work. As a result of his seven-day-a-week dedication to perfect his skill as an artist, Keating produced a record of his emerging sense of personal and national identity analogous to the ever-changing socio-political contexts ${ }^{8}$.

4 Focusing on the role of dress and costume in self-portraiture, we purport to view Keating's self-images from a different perspective. Self-portraits in costume are indeed not merely staged images of the self but also performative acts since costuming induces impersonation. Identity is therefore performed as well as staged and pictured. Starting from costume and dress as identity markers or shifters, we argue that self-portraits may, in the case of Keating and in the specific context of Irish nationalism, be a form of political embodiment.

\section{Playing with identities: the costumed painter}

In the painter's Early Self-portrait, a three-quarter-length portrait painted around 1907-11 (private collection) ${ }^{9}$, Keating stands on the side of the composition, clad in a black suit which bespeaks his modesty. The shy gaze, the hazy outlines of the face and the softness of the brushstrokes betray the artist's secretive personality. Featuring a female model in the middleground, this composition hints at the practice of drawing from life which was usual at the academy and testifies to Keating's classical approach to painting: "Keating then is a traditional painter whose work is based on pure draughtsmanship" ${ }^{10}$. The plainness of the suit, blending in the brown background, suggests that the garb is hardly a dress or a costume. Keating was aware of the conventions of self-portraiture. In a much later, though not dated work, Self-portrait with palette ${ }^{11}$, he follows a well-established tradition dating back to Holbein (Self-portrait, 1542, Uffizi, Florence) and Rembrandt (Selfportrait with Beret and Turned-up collar, 1659, National Gallery of Art, Washington) consisting in painting oneself in the act of painting. Contrary to the early likeness, the canvas is imbued with a sense of determination and commitment. The dark clothes of the painter, almost merging into the plain background, reveal his taste for frugality and simplicity consistent with his sympathies with the socialist movement and his tendency to "proletarianize his childhood"12. These two self-portraits conform with the rules of a genre in which "being human, artists may wish to present the image they want us to have of them, or indeed to create the ideal to which they aspire ${ }^{13}$." However, in most of his other self-portraits, Keating explores the decorative and theatrical potentialities of costume in an original manner.

6 Maybe out of necessity, during the early years of his career, the painter regularly staged himself and his relatives ${ }^{14}$ in photographic tableaux which he then copied into paintings ${ }^{15}$. Some great masters inserted their likenesses into narrative scenes either as a signature or as a form of impersonation, using costumes and accessories playfully ${ }^{16}$. Philippe Lejeune notes that the line between reality and fiction may be very thin in some autobiographical projects or projections ${ }^{17}$. This applies to self-portraits as well: painters may portray themselves in costume either because the garb, as a material artefact, fascinates them, or 
to indulge in role-playing, using dress as a form of sartorial escapism, or to reveal something about their own personality surrepticiously.

7 Between 1916 and 1919, Keating painted Self-Portrait in a Bear Skin ${ }^{18}$ matching a similar portrait of his sister. In the two works, the disproportionately large fur cloak-which is painted very convincingly-is the main focus, as the title suggests. The garment was either borrowed from the National Museum of Ireland, or brought back from Russia by one of Keating's brothers. The D.M.S.A., which was situated nearby museums, provided "a colourful wardrobe of costumes and props" ${ }^{19}$. While Mary Frances Keating, who modelled for the portrait, shyly disappears under the bulky garment, her brother, holding a spear as a primitive hunter would, stares at the viewer in a self-confident manner, visibly relishing the role-playing. The painter's interest in the rendering of materials and fabrics will have been encouraged by Orpen while the attention that is paid to the decorative elements on the coat foreshadows the ethnographic accuracy of some later paintings. Keating portrays himself as a confident man as if emboldened by the attire. It is interesting to note that the painting was subsequently featured in an exhibition at the Aonach Tailteann under the title Ligimte Stoc, I Declare Leadershi ${ }^{20}$. Such a shift in the title reinforces the wavering between identity and persona which is constant in these costumed stagings as the clothing leads to fictitious embodiments and identity plays.

A few years later, Keating painted himself in a less outlandish costume in Fear Sorrdha ( Man at Ease $)^{21}$. In this three-quarter portrait, he is dressed in a white shirt and wrapped in an elegant striped shawl. A black hat is elaborately tilted on his head, topping a chequered headscarf. The sophiscated and eccentric attire reflects Keating's-real or fantasized-bohemian lifestyle at that time even though the portrait is visibly contrived. The painter, or the painter's persona, or the fictitious character impersonated by Keating, gazes at the viewer in a self-assured manner. The work is not identified as a self-portrait so that Keating plays with the indeterminacy specific to the genre. Is Keating offering the viewer a parody of himself as 'the painter in his gown' after Rembrandt or Hogarth? Or is the painter venting his own eccentricity through costuming? If these questions are difficult to answer, Keating's taste for playful costuming seems obvious. Another selfportrait, probably from the same period, shows the artist in an Arab costume ${ }^{22}$. The emphasis is placed on the folds and patterns of the clothes foreshadowing his later interest in exotic dress. As James Hall notices, "even when an artist's self-portrait seems to be the result of a genuine moment of self-regard or self-interrogation, it is invariably a kind of performance. In many cases [...] the role-playing is overt; [...] what appears to be a literal representation of the artist is in reality a complicated and conscious fabrication: it is virtually impossible not to self-consciously construct your own image" 23 . These selfportraits in costumes must therefore be viewed as performative practices through which the painter explores alternative selves and derides social or artistic conventions. The viewers's eagerness to be given a glimpse at the artist's true self is flouted as it is impossible to disentangle earnestness from fantasy. In that respect, Hall notes that "one of the wonders of self-portraits is their capacity to induce unique levels of uncertainty in the viewer ${ }^{24}$."

\section{Costume as ethnographic document}

Along the self-portraits resulting from theatrical impersonations, Keating painted likenesses of himself in traditional Irish costume. As early as 1915, in Men of The West ${ }^{25}$, 
Keating, who included himself in the composition, dressed the characters in traditional clothing, an "exotic dress ${ }^{26}$." The costumes, from the Connacht region, are not meant to be realistic although the painter represents them with ample detail and enhances the crios (traditional woven belts) and patterned scarves. Many of his compositions in oil, pastel or watercolor foreground Irish clothes with elaborate patterns, embroidered shawls or traditional knitware. Even in his religious canvases, Keating clothed the characters in differentiated garments enhancing the colours and the intricacy of the patterns ${ }^{27}$. The artistic interest in regional costume was initiated by many Irish painters who depicted Irish folks in brightly coloured dress: Aloysius O'Kelly (1853-1936), Walter Osborne (1859-1903), Harry Jones Thaddeus (1859-1929), Paul Henry (1877-1958), as well as the English painter Charles Lamb (1893-1964) studied regional attire. Yet Keating did not contend himself with painting costumes but actually wore them therefore adding embodied performance to representation.

In 1909, William Orpen, who also painted several self-portraits in costume, portrayed himself in Aran garb. The Anglo-Irish painter wanted to "engage with, satirize, mask, elaborate and fantasize his identities" 28 . His self-portraits in costume may therefore be dismissed as masquerade. His Aran outfit, to be derided maybe as a "camp Celtic revival fantasy" ${ }^{29}$, is all the more puzzling as Orpen was of Protestant origin and considered himself as an Englishman. Though Keating may owe his interest in dress to his master, his use of costume is far from illustrating the modernist indeterminacy of the self which may find an echo in Orpen's output. As a matter of fact, while Keating happened to give into costuming as a simple theatrical performance, the consistency in his choice of attire suggests a deeper commitment.

11 As early as the mid-19 $9^{\text {th }}$ century, throughout Europe, painters showed an interest in vernacular culture and folklore ${ }^{30}$. Such cross-European ethnographic curiosity, tinged with romanticism, was tied to political and cultural discourses on nationhood ${ }^{31}$. Artists turned to their ethno-cultural heritage as well as to peasant communities epitomizing national ideals as a source of inspiration ${ }^{32}$. The exhibition in academies and Salons of paintings portraying folks in regional costumes, performing traditional tasks and surrounded by ethnographic objects played a role in the dissemination of nationalist ideals so that folklore was interpreted as national tradition and "rustic popular culture was canonized into the very essence and bedrock of national identity" ${ }^{33}$. Marie Bourke showed that "by using imagery associated with the west in a new and inventive manner, [Irish artists] were able to develop a body of work that looked distinctively Irish" ${ }^{34}$.

Departing from the romantic or impressionist styles characterizing depictions of the West of Ireland, Keating forged an idiosyncratic manner. The blatant theatricality of his compositions enables him to eschew the issue of authenticity tied to Western exoticism and offer a symbolical approach to costume. As a matter of fact, it is difficult to know whether the Aran costume that Keating painted with much care was still worn on a daily basis at the time. Anthropologists, focusing on Robert Flaherty's 1934 film, Man of Aran, have questioned the realism of his depictions and argued that the Araners' outfit was a reconstructed reality ${ }^{35}$. The colour photographs which French scholar Marguerite Mespoulet shot in 1913 in the West of Ireland for the Khan Archives are rare testimonial documents. Struck by the poverty and dignity of the Irish people she met, she photographed people both in ragged clothes and in bright red garments ${ }^{36}$. Compared to these images, Keating's depictions seem idealized. Although several of his canvases draw 
attention to the plight of the Connacht people, his representation of costumes is never meant to trigger compassion.

In ethnographic descriptions, regional dress is a preeminent badge of identity. Similarly, in regionalist painting, traditional costumes become signifiers of identity. "Clothing is a palpable, immediate, and intimate form of material culture", professor of folklore Pravina Shulka notes. "Sending meaningful messages through dress is one way people engage in a daily artful endeavor, participating in what folklorists call 'creativity in everyday life' or 'artistic communication in small groups"' ${ }^{37}$. An outlet for cultural expression, the colourful costume of the West counties emblematized cultural distinctiveness but was also the symbol of rusticity ${ }^{38}$. Keating painted himself-and his wife at times-in traditional Irish costume in works whose titles evoke types rather than individuals. Good Evenin' Miss, $1921^{39}$, a double full-length portrait based on a photograph of the couple dressed as country folks, was painted in studio but is supposed to be set in the Aran Islands. "The style and atmosphere of the work had more to do with Irish theatre at the time than with the reality of life on the islands" ${ }^{40}$. Painted in 1921, in the context of intense political turmoil, the painting conjures up Synge's literary representations of the Aran Islands and exemplifies the ethnographic genre scene which thrived at the academy ${ }^{41}$. The couple, in colourful costume, is merrily dancing on the road as if performing on stage. Folk dance stands for the primitive sociability of country folks and the idea of community bonding which delighted many travelers from urban areas. In Trevor Thomas Fowler's Children Dancing at Crossroads (c. 1830) or Charles Lamb's Dancing at a Northern Crossroads (1920) country people are also dancing happily. However, whereas in Fowler's scene the young dancers are in rags, which brings forth images of poverty, in Lamb's and Keating's compositions the garments are colourful and exotic ${ }^{42}$. Besides, in Keating's selfportraits, the process of impersonation strengthens the scope of the sartorial depiction: when worn, "costume [...] allows us to transcend the here and now, allowing for a deeper communication of meaning 43 ." As a matter of fact, Keating's fascination with vernacular dress and ethnographic costume does not solely spring from a taste for folklore. The garb conveys specific values and ideals.

In 1915, William Orpen portrayed Keating in Aran costume in a work bearing a telling double title: Man of Aran. Sean Keating ${ }^{44}$. While in his self-portrait in Aran dress Orpen looked elegant, Keating seems humble, somber and stern. Orpen "created an iconic visual identity for his former student" as "the painting embodies everything that Keating must have expressed to Orpen about his nationalist sympathies and about his attitude to the Aran Islands ${ }^{45}$." Keating also features in Orpen's The Holy Well (1915): he is dressed in typical Aran costume (hat, pampooties, crios and woollen waistcoat). Standing on a hillock, he dominates the scene of blind piety and embodies the future of the nation. Just behind him, an old tree is burgeoning, a symbol of rebirth through the revival of roots.

Although Keating's self-portraits in Aran gear bear titles which draw attention to the costume -Self-portrait Wearing a Hat (1930s, private collection ${ }^{46}$ ) or Self-portrait in a Bainín Hat (c. 1937-40, private collection $\left.{ }^{47}\right)$-the clothing is more than an object of ethnographic curiosity: it is a visual means to express faith in values and ideals.

16 Keating painted himself in the role of Christy Mahon's father in John Millington Synge's The Playboy of the Western World ${ }^{48}$. The playwright claimed that his depiction was rooted in his direct observations of Araners compiled in The Aran Islands (a text straddling ethnographic realism and romantic invention) and accompanied by a portfolio of photographs. Keating's compositions are visibly contrived and, as Éimear O'Connor 
suggests, his impersonation of Christy Mahon's father "suggests a wide range of symbolic implications allied to Synge's metaphorical vision ${ }^{49}$."

While costume is generally construed as a means to conceal oneself or to be someone we are not, Pravina Shukla notes that it is "the clothing of who we are but [...] it signals a different self, one other than that expressed through daily dress"50. Of the Aran Islands, Keating wrote: "One of the advantages of a place like Aran is that you have to look into yourself and perhaps discover that you haven't got a self, a discovery that cannot be made too soon in the case of a painter...." By dressing as a man of Aran, Keating transposes his life to a region and a time period which he saw as the epitome of Irishness. Given that self-portraits are visual statements, the clothing of the artist is "deliberately used to project an elected identity specific to the time, place, and audience" ${ }^{52}$. Selfportraying himself in such gear enabled Keating to convey a message: through painting, the impersonation is made permanent and assertive. The artist becomes and shows himself as the one he wished to be, a simple Aran man. As Shukla notes, costume may be used to construct a self-conscious presentation of oneself and "functions to help individuals elect, embrace, and display special identities." "Special dress, she claims, enables the expression of extraordinary identity in exceptional circumstances" 53 .By portraying himself in Aran dress, Keating voices his endorsement of the nationalist ideal premised on an idealized West. In these self-portraits, the artist's body is allegorized. From one self-portrait to another, Keating's face ages but hardly varies as he intends to embody a generic type rather than an individual. The sharpness of his features, his vivid blue eyes and wrinkles stand for the dignity of the Aran people. As Brian Graham writes, Keating "complemented the literary Wests of Pearse and de Valera, his paintings portraying a heroic society inhabiting its wild landscapes" ${ }^{54}$. To a certain extent, the face of the artist as an Araner becomes a mask and brings to mind Oscar Wilde's quip that "man is least himself when he talks in his own person. Give him a mask, and he will tell you the truth" 5 .

\section{Political embodiment}

"In every self-portrait we discover individuals who wish to portray not just likenesses or even inner worlds, but concrete facts about who they were, what they could achieve and how they fitted in to the world around them" ${ }^{56}$. While he did not paint straightforward historical scenes, Keating clearly voiced his political opinions through his paintings. As James White observes,

during the years of revolution and those which followed the foundation of our state [Keating] has painted pictures which assert primary values and decry the attitude of the ephemeral and the less-than-honest opportunists who were quick to exploit the new situation. [...] He was creating a new type of Irish man $^{57}$.

Because "nations are conceptual, emotional, abstract entities which may be associated with a state, but can only be grasped through their representations, [and] symbols ${ }^{58}$ " artworks do play a role in nation-building. In the context of Irish nationalist struggle, "literary and visual artists were attracted to the West of Ireland in their search for a new means or language to express a positively empowered cultural Irish identity in art" ${ }^{59}$. Men of the West is indeed "a personal, visionary response to developing events" and a "romanticized image of the Irish fighting men of the time"60. By costuming as a nationalist fighter and placing his own figure just in front of the tricolour symbolising the 
emerging nation, next to his brother Joe Hannan (a member of the IRB), Keating devises a pictural call to arms. More than creating a national type, he embodies the new independent Irish man and we may construe the performative nature of his self-portraits as empowerment. One could interpret a watercolour entitled Spanish Arch (c. 1916) ${ }^{61}$ as a similar statement since Keating, dressed in full Aran costume, is reclining on a stone wall turning his gaze away from a rifle as if to suggest that he has chosen a non-violent way to fight. Painted just one year before the Easter Rising, Men of the West became iconic and Keating edited prints of the work in 1919 to raise funds for families affected by the national struggle. The prints were subsequently banned as the image was considered dissident. Keating remained "as close as the Irish national movement would come to an official artist" ${ }^{\prime 2}$. He was affected by the ban of the poster and he "may have been concerned about attracting further unwarranted attention"63. Men of the South, which harps on the same subject, was exhibited only in 1922 after the Treaty of Independence was signed and Keating is absent from the composition. Even though he never took the arms, the artist used his paintings to promote the new independent nation.

All through his life, Keating's art followed the development of the nation. In 1924, the painter portrayed himself, powerless and exhausted, in An Allegory ${ }^{64}$ (National Gallery). The painting testifies to Keating's disillusionment after the Civil War: the ruined mansion in the background, the coffin covered with the tricolour, the distance between the politician and the people burying their friends represent the failure of the Republican project that Keating had supported. In 1929, Keating pictured himself, his wife and two sons in Night's Candles are Burnt Out (Gallery Oldham). In the painting, Keating is showing the young boy, the dam under construction and his gesture leads the viewers' gaze to this symbol of modernity. The Ardnacrusha scheme was indeed tightly keyed to the emergence of the modern nation. The artist stands on a par with the workers and is dressed like them, considering himself as an artisan of national modernity. He used the same family group for the frontispiece of the Nationalist Ideal in 1931; he and his wife point at the hammer and sickle as well as the cross, the symbol of Russian socialism and Christianity. Keating's status here is multiple: a painter, a father and head of family as well as a citizen of the nation.

21 The omnispresence of the painter adopting various though consistent identities demonstrates that the artist, in his view, must bear witness to the historical developments of his country. To do so, the painter adopts a visual language that can aptly transcend reality to put across ideals and values. As James Hall argues, self-portraits are not passive reflections of their own societies but influence their own society's sense of identity and selfhood ${ }^{65}$. The embedded self-portraits enable the painter to make a statement about the role of artists in society. Keating's self-allegoricisation, both as an artist and as a citizen, fulfills his commitment to national socialism in that his self serves the ideal of the nation and he represents himself as fully involved in his society.

\section{Conclusion}

Seán Keating used dress and costume in a particularly rich and complex way confirming that "costume is [...] extraordinary in its semantic elaboration; it makes explicit references, whether political, social, historical, religious, aesthetic, or psychological" 66 . With a penchant for disguise, he explored dress and clothing as visually efficient signifiers of identity. Self-portrayal and the impersonation it induces are to be 
understood as political embodiment: Keating fought artistic and political battles in his compositions using his own image and costume as allegories. Although a couple of years separate their self-portraits, one cannot help thinking of Frida Kahlo's self-portraits in costume and the way she also used her physical body and her painted image as epitomes of an oppressed regional identity. Scrutinizing Keating's multiple usages of dress and costume may therefore incite us to consider his commitment differently. Although his impersonations served the nationalist and national causes, they did so in an inventive and empowering way. His use of photography, his taste for performance as well as his exploration of the potentialities of costuming were indeed singular.

\section{NOTES}

1. Éimear O'Connor, Seán Keating, Art, Politics and Building the Irish Nation, Irish Academic Press, Dublin, 2013, p. 14.

2. Ibid., p. 45.

3. Keating occupies a central place in XXth century Irish art: in 1919 he was appointed associate teacher at the Dublin Metropolitan School of Art (D.M.S.A); in 1923 he became Professor of Painting and was elected a member of the Royal Hibernian Academy (R.H.A); in 1934 he was appointed Professor of the National College of Art in Dublin (N.C.A.D.); he was President of the R.H.A. (where he exhibited around 300 works) from 1948 until 1962.

4. "He continued to follow Orpen's principles and practices for commissioned portraits" though he seldom gave into flattering or idealized portraits. O'Connor, op. cit., pp. 54-55.

5. Ibid., p. 26.

6. Ibid., p. 14.

7. « Costume, texte écrit, attitude, rien n'appartient au hazard; nul detail n'est accessoire. Tout est chiffre, marqué du sceau de l'identité; tout ce dont le portrait est empreint est à déchiffrer ». Pascal Bonafoux, Les Peintres et l'autoportrait, Genève, Skira, 1984, p. 14.

8. Ibid., p. 52.

9. Ibid., p. 31, pl. 6. The painting bears a striking resemblance with a self-portrait by William Orpen dated 1911, Myself and Venus (1910, Carnegie Museum of Art, Pittsburg), the year when Keating met him in Dublin. http://www.cmoa.org/CollectionDetail.aspx? item=1000442\&retPrompt=Back+to+Results\&retUrl=CollectionSearch.aspx\%3Fsrch\% 3DOrpen\%252c\%2BWilliam (Accessed January 2018).

10. James White, Royal Hibernian Academy of Arts, Dublin, Exhibition catalogue, 1989, unpaginated.

11. http://themodel.ie/the-niland-collection/collection/123 (Accessed January 2018), $49 \times$ $59.25 \mathrm{~cm}$, oil on canvas, Niland Collection. The canvas is redolent of Frédéric Bazille's selfportrait (1865, Art Institute Chicago), both painters sitting against a plain grey background and holding their palettes almost defiantly.

12. O'Connor, op. cit., pp. 26-27.

Études irlandaises, 43-1 | 2018 
13. Anthony Bond, "Performing the Self", http://anthonybond.com.au/wp/wp-content/ uploads/2015/03/performing-the-self.pdf, p. 1. (Accessed January 2018).

14. His brother Joseph Keating, who was a member of the Irish Republican Brotherhood (O'Connor, op. cit., p. 34) is featured in several canvases (Men of the West, 1915; Ar a gCoimead, 1919; On the Run, War of Independence, 1922). His sister, Vera, is portrayed is less political works (The Bear Skin, 1915; Girl in a Black Fur Coat, 1916; The Feast of St Brigid, 1918). His wife, May, modelled for a considerable number of paintings.

15. The painter had a great interest in photography and owned a cine-camera as well as an epidiascope, used to project images onto the canvas. He photographed himself and other actors in costume and used the photographs, traced with grids, as a guide for the positioning of the figures. O'Connor, op. cit., p. 49.

16. Already in his Vite, 1598, Vasari registered 80 painters who featured in their own narrative scenes (Bonafoux, op. cit., p. 15). Gustave Courbet's self-portraits for instance show him in a variety of costumes playing roles in a most dramatic manner.

17. Philippe Lejeune, Le Pacte autobiographique, Paris, Editions du Seuil, 1975, p. 25.

18. $92 \mathrm{x} 76 \mathrm{~cm}$, private collection, http://www.sothebys.com/en/auctions/ ecatalogue/2016/irish-art-116134/lot.20.html (Accessed January 2018).

19. O'Connor, op. cit., p. 49.

20. See http://www.invaluable.com/auction-lot/sean-keating,-p.r.h.a.-31-c-a56a6e3e58 (Accessed January 2018).

21. Private collection. O'Connor, op. cit., p. 78, pl. 2. and http://www.sothebys.com/en/ auctions/ecatalogue/2012/british-and-irish-art/lot.149.html (Accessed January 2018).

22. Private collection, formerly owned by the Victor Waddington Gallery, Dublin.

23. Bond, op. cit., p. 12.

24. James Hall, The Self-portrait, a Cultural History, London, Thames and Hudson, 2014, p. 9.

25. 91 x $125 \mathrm{~cm}$, Dublin City Gallery, The Hugh Lane.

26. Fintan Cullen, The Irish Face, Redefining the Irish Portrait, London, National Portrait Gallery, 2004, p. 220.

27. In the Stations he painted for Conglowes Wood College (1919-22) the costumes are highly detailed. From 1955 to 1958, Keating worked on a set of Stations of the Cross for St John's Church in Tralee, County Kerry. The paintings are based on photographic tableaux in which the painter embodies Christ

28. Angeria Rigamonti di Cutò, "Staging the Modernist Self: The Self-Portraits of William Orpen”, Visual Culture in Britain, 14 November 2012, http://www.tandfonline.com/doi/ abs/10.1080/14714787.2012.716980?src=recsys\&journalCode=rvcb20 (Accessed January 2018).

29. Ibid.

30. See Valérie Morisson, "The Guise of Irishness: Irish Ethnographic and Folkloric Paintings from a European Perspective, 1880-1930", Revue Miroirs, n² 2, 2015, Irlande: Identité et interculturalité / Ireland: Identity and Interculturality (dir. Bairbre Ní Chiosáin et Charlotte Rault) - http://www.revuemiroirs.fr/larevue.html (Accessed January 2018).

31. T. Baycroft and D. Hopkins (ed), Folklore and Nationalism in Europe during the Long 19th Century, Brill Academic Pub Baycroft and Hopkins, 2012, pp. 2-3. 
32. See Athena S. Leoussi, "The Etno-cultural Roots of National Art", in Guibernau, G. and Hutchinson, J., History and National Destiny: Ethnosymbolism and its Critics, Oxford, Blackwell Publishing Ltd, 2004, pp. 143-160.

33. J. Leerssen, National Thought in Europe, Amsterdam, Amsterdam University Press, 2006, p. 195.

34. Marie Bourke, "A Growing Sense of National Identity: Charles Lamb (1893-1964) and the West of Ireland", History Ireland, Vol. 8, no. 1, 2000, p. 30.

35. See Valérie Morisson, "Men of Aran: Strangers on the Fringe of Europe", in C. Dubois et V. Alayric (dir.) The Foreignness of Foreigners, Cambridge Scholars, 2015, pp. 125-147 and Cally Blackman, "Colouring the Claddagh: A Distorted View?", Costume, vol. 48, no. 2, pp. 213-235.

36. David Okuefuna, Albert Khan, Le Monde en couleurs, Autochromes 1908-1931, Paris, Chêne, 2008, pp. 42-51.

37. Pravina Shukla, Costume: Performing Identities through Dress, Indiana University Press, 2015.

38. Morisson, 2015, op. cit.

39. Private collection. The work was exhibited at the R.H.A. and purchased by a friend of the artist. O'Connor, op. cit., p. 128, pl. 10.

40. Ibid., p. 127.

41. Ethnographic painting had come to fame in Paris, and at the Académie des BeauxArts, thanks to Théodore Valerio and Jean-Léon Gérôme. On this European genre see Morisson, 2015, op. cit.

42. Many parallels were drawn between the Western counties and southern or oriental countries in ethnographic or pseudo-ethnographic writings. See Morisson, 2015, op. cit.

43. Shukla, op. cit., p. 15.

44. Limerick City Gallery. Image available at http://www.estudiosirlandeses.org/ wpcontent/uploads/2013/05/Orpen-Man-of-the-West.jpg (Accessed January 2018).

45. Orpen never empathized with the islanders and failed to share his pupil's nationalist ideas. O'Connor, op. cit., p. 58.

46. Ibid., p. 53, pl. 7 .

47. Ibid., p. 54, pl. 8 .

48. Private collection. A set of ten paintings was commissioned by Synge's executors for a deluxe edition of the play. Keating used the Abbey Theater actors as models for the illustrations except in two images. See O'Connor, op.cit., pp. 119-121.

49. Ibid., p. 119.

50. Shukla, op. cit., p. 4.

51. O'Connor, op. cit., p. 113.

52. Shukla, op. cit., p. 15.

53. Ibid., p. 4.

54. Brian Graham (ed.), In Search of Ireland: a Cultural Geography, London, Routledge, 1997, p. 47.

55. The Critic as Artist, quoted in Brian Graham (ed.), In Search of Ireland: a Cultural Geography, London, Routledge, 1997, p. 238. 
56. Bond, op. cit., p. 12.

57. White, op. cit.

58. Baycroft, op. cit., p. 3.

59. E. F. Martin, "Painting the Irish West: Nationalism and the Representation of Women", New Hibernia Review, vol. 7, $\mathrm{n}^{\circ}$ 1, Spring 2003, pp. 31-44, p. 31.

60. Sighle Bhrethnach-Lynch, “Framing Ireland's History, Art, Politics, and Representation, 1914-1929" in J.C. Steward, When Time Began to Rant and Rage, Figurative Painting from Twentieth Century Ireland, London, Merrell Holberton, 1999, p. 43.

61. Leicester Galleries, http://www.leicestergalleries.com/19th-20th-century-paintings/ d/sean-keating/13222 (Accessed January 2018).

62. Catherine Marshall, Fintan O'Toole, “Modern Ireland in 100 Artworks: 1917 - Men of the West, by Seán Keating", http://www.irishtimes.com/culture/modern-ireland-in-100artworks-1917-men-of-the-west-by-se\%C3\%A1n-keating-1.1999687 (Accessed January 2018).

63. O'Connor, op. cit., p. 66.

64. For a detailed analysis of this work see Síghle Bhreathnach-Lynch, "Crossing the Rubicon: Sean Keating's An Allegory," New Hibernia Review (https://muse.jhu.edu/ journal/141), Volume 12, $\mathrm{n}^{\circ}$ 2, Summer 2008 (https://muse.jhu.edu/issue/12860), pp. 120-126.

65. Hall, op. cit., p. 11.

66. Shukla, op. cit., p. 14.

\section{ABSTRACTS}

The paintings of Irish artist Seán Keating (1889-1977) have admittedly contributed to asserting an Irish identity blending tradition and modernity. Seen from this perspective, his numerous self-portraits may be viewed as a means to embody a political ideal. His self-portraits in costume deserve more attention than they have received so far. As a matter of fact, Keating revisits a long tradition consisting in playfully painting oneself in disguise. However, he also resorts to costuming to serve a political cause. By dressing up as an Araner or by portraying himself in traditional attire in nationalist canvases, Keating embodies his political ideas and states that the place of the artist is in the midst of the nation and society.

L'œuvre du peintre irlandais Seán Keating (1889-1977) a accompagné l'affirmation d'une irlandité mêlant tradition et modernité. Dans cette perspective, les nombreux autoportraits de l'artiste peuvent être considérés comme un moyen d'incarner un idéal politique. Le recours au costume dans ses autoportraits mérite attention. En effet, Keating reprend une tradition picturale bien établie en se représentant de manière ludique en costume mais utilise le dispositif de manière plus politique. En revêtant le costume traditionnel des habitants des îles d'Aran ou bien en se portraiturant en habit traditionnel dans des compositions aux accents nationalistes, 
Keating incarne des idées politiques et affirme que la place de l'artiste est au cœur de la nation et de la société.

\section{INDEX}

Keywords: Aran Islands, body, cultural nationalism, ethnography, folklore, visual arts, Keating, Seán, painting, costume

Mots-clés: Iles d'Aran, corps, nationalisme culturel, ethnographie, folklore, arts visuels, Keating, Seán, peinture, costume

\section{AUTHOR}

\section{VALÉRIE MORISSON}

Université de Bourgogne Franche-Comté, TIL EA 4182. Valérie Morisson is a lecturer in English at the University of Burgundy, Dijon, France. Her research is on Irish contemporary art and its relation with post-nationalist culture. She investigates how political, social, and cultural evolutions in the Republic of Ireland and Northern Ireland are reflected in visual culture (painting, sculpture, installation, performance, video, photography). Her articles focus on a wide range of subjects ranging from feminist art, the issue of memory and the commemoration of history, to post-nationalist revisionism and the Northern-Irish situation as reflected in art. Several of her articles tackle photography and performance art in both an Irish and a European perspective. Her recent research addresses wider artistic issues in both the Irish and the English domains such as the role of archives and field work in the creation process or the use of discarded materials and the reemergence of materiality in contemporary art. 